\title{
Influence of gibberellin inhibitors applied during flowering of nonirrigated 'Hass' avocado trees
}

\author{
Bruna do Amaral Brogio(1), Simone Rodrigues da Silva(1), Tatiana Cantuarias-Avilés(1), \\ Sérgio Figueiredo Angolini( ${ }^{(1)}$, Edypol Guilherme Baptista ${ }^{(1)}$ and Rafael Vasconcelos Ribeiro ${ }^{(2)}$
}

\begin{abstract}
(1)Universidade de São Paulo, Escola Superior de Agricultura Luiz de Queiroz, Departamento de Produção Vegetal, Avenida Pádua Dias, no 11, Caixa Postal 9, CEP 13418-900 Piracicaba, SP, Brazil. E-mail: brunabrogio@usp.br, srsilva@usp.br, tatiana.cantuarias@gmail.com, sergio.angolini@usp.br, edypol_0@hotmail.com ${ }^{(2)}$ Universidade Estadual de Campinas, Instituto de Biologia, Departamento de Biologia Vegetal, Rua Monteiro Lobato, no 255, Barão Geraldo, CEP 13083-970 Campinas, SP, Brazil. E-mail: rvr@unicamp.br
\end{abstract}

\begin{abstract}
The objective of this work was to evaluate the effect of different gibberellin biosynthesis inhibitors on shoot growth above the panicle, as well as on fruit yield, size, and shape of nonirrigated 'Hass' avocado (Persea americana) trees. The experiment was carried out in a randomized complete block design, with five treatments, four replicates, and 40 trees. From 2013 to 2015, the following treatments were applied at full bloom, as foliar sprayings: water (control), $250 \mathrm{mg} \mathrm{L}^{-1}$ prohexadione-calcium, 2,500 $\mathrm{mg} \mathrm{L}^{-1}$ trinexapac-ethyl, $1,750 \mathrm{mg} \mathrm{L}^{-1}$ paclobutrazol, and $350 \mathrm{mg} \mathrm{L}^{-1}$ uniconazole; the first two are acylcyclohexanediones and the last two, triazoles. Fruit yield, yield efficiency, and alternate bearing were not affected by the application of plant growth regulators. However, the gibberellin inhibitors increased fruit size and modified the fruit shape of nonirrigated 'Hass' avocado. Uniconazole reduces shoot growth above the panicle, and this effect may vary depending on environmental conditions, especially water supply.
\end{abstract}

Index terms: Persea americana, acylcyclohexanediones, production, triazoles.

\section{Influência de inibidores de giberelinas aplicados no florescimento de abacateiros 'Hass' não irrigados}

\begin{abstract}
Resumo - O objetivo deste trabalho foi avaliar o efeito de diferentes inibidores da biossíntese de giberelinas no crescimento dos brotos acima da panícula, bem como na produção, no tamanho e no formato de frutos de abacateiro (Persea americana) 'Hass' não irrigado. O experimento foi conduzido em delineamento de blocos ao acaso, com cinco tratamentos, quatro repetições e 40 árvores. De 2013 a 2015, foram aplicados os seguintes tratamentos, no florescimento, via pulverização foliar: água (testemunha), $250 \mathrm{mg} \mathrm{L}^{-1}$ de prohexadione-cálcio, $2.500 \mathrm{mg} \mathrm{L}^{-1}$ de trinexapaque-etílico, $1.750 \mathrm{mg} \mathrm{L}^{-1}$ de paclobutrazol e $350 \mathrm{mg} \mathrm{L}^{-1}$ de uniconazole; os dois primeiros são acilciclohexanodionas e os dois segundos triazóis. A produção de frutos, a eficiência produtiva e a alternância produtiva não foram afetadas pela aplicação dos fitorreguladores. Entretanto, os inibidores de giberelinas proporcionaram frutos de maior tamanho e modificaram o formato de abacates 'Hass' não irrigados. O uniconazole reduz o crescimento dos brotos acima da panícula, e esse efeito pode variar de acordo com as condições ambientais, especialmente com a disponibilidade de água.
\end{abstract}

Termos para indexação: Persea americana, acilciclohexanodionas, produção, triazóis.

\section{Introduction}

Brazil has excellent soil and climate conditions for avocado (Persea americana Mill., Lauraceae) production. However, the expansion of the growing area is limited by several factors, such as: the nonadoption of high planting density and of agronomic managements for improving fruit production and quality (Menzel \& Le Lagadec, 2014); the presence of Phytophthora cinnamomi, the main pathogen that threatens avocado production worldwide (AcostaMuñiz et al., 2012); and the cultivation of most of the local commercial orchards under rainfed conditions. Avocado productivity is also reduced by alternate bearing (Whiley et al., 2013), excessive vigor (Lovatt, 2005), and a low fruit set rate, due to the intense competition of flowers and fruitlets with the new vegetative shoot developing above the panicles (Symons \& Wolstenholme, 1990).

In order to manage these limitations and increase fruit yield, the application of phytoregulators has been adopted in the main avocado producing countries (Lovatt, 2005). Several studies conducted in irrigated 
orchards of 'Hass' avocado, the main cultivar planted around the world, have shown the effectiveness of applying phytoregulators in the bloom period, with improvements in fruit yield and size, increasing the economic return to growers (Erasmus \& Brooks, 1998; Lovatt, 2005). The most widely adopted phytoregulators in irrigated avocado orchards are gibberellin biosynthesis inhibitors, particularly the triazoles paclobutrazol and uniconazole (Menzel \& Le Lagadec, 2014). Symons \& Wolstenholme (1990) pointed out that the intense competition for resources between the shoot growing above the panicle and the concurrently developing flowers and newly set fruit is mitigated by the application of gibberellin inhibitors.

In Brazil, previous studies have reported the use of the following gibberellin biosynthesis inhibitors: paclobutrazol (Cardoso et al., 2007; Mouco et al., 2010; Upreti et al., 2013; Chatzivagiannis et al., 2014), uniconazole (Silva et al., 2010), and trinexapac-ethyl in mango (Mangifera indica L.) trees (Mouco et al., 2010, 2011, 2013); and prohexadione-calcium in apple (Malus domestica Borkh) trees (Hawerroth et al., 2012; Hawerroth \& Preti, 2014). However, no studies have been reported on the use of these phytoregulators in nonirrigated avocado trees. In the current scenario of global climate changes and increasing water shortage, it is extremely important to validate managements that may be efficient and beneficial for agricultural production under restricted water availability.
The objective of this work was to evaluate the effect of different gibberellin biosynthesis inhibitors on shoot growth above the panicle, as well as on fruit yield, size, and shape of nonirrigated 'Hass' avocado trees.

\section{Materials and Methods}

The experiment was carried out between 2013 and 2016, in nonirrigated 'Hass' avocado trees managed following the recommendations for the crop (Schaffer et al., 2013). The orchard was established in 2009 at 8x6-m spacing, in a Latossolo Vermelho distrófico (Santos et al., 2013), i.e., a Typic Haplorthox, in the southwestern region of the state of São Paulo, Brazil. The climate of the region is Cwa, according to KöppenGeiger's classification, subtropical, rainy in summer and dry in winter. Meteorological data were collected by an automated weather station installed in the field (Figure 1). The trial was set in a randomized complete block design, with five treatments, four replicates, and two plants per plot, totaling 40 trees under evaluation.

The trees were sprayed with the following treatments: water, as a control; $250 \mathrm{mg} \mathrm{L}^{-1}$ of the acylcyclohexanedione prohexadione-calcium; 2,500 $\mathrm{mg} \mathrm{L}^{-1}$ of the acylcyclohexanedione trinexapac-ethyl; $1,750 \mathrm{mg} \mathrm{L}^{-1}$ of the triazole paclobutrazol; and $350 \mathrm{mg} \mathrm{L}^{-1}$ of the triazole uniconazole; the application dates were September 12, 2013, August 5, 2014, and August 16, 2015 , at full bloom, when more than $50 \%$ of the canopy surface had open flowers. A mean spray mix volume of $4.0 \mathrm{~L}$ per plant was applied on the leaves to the drip

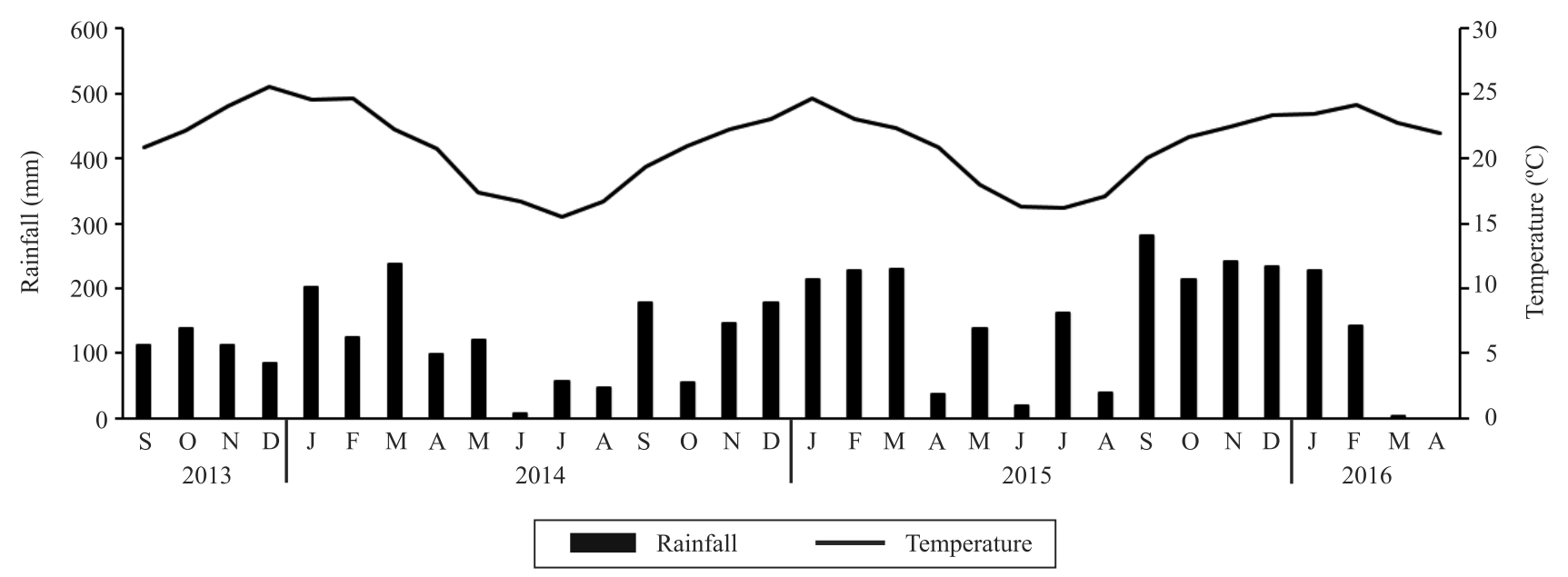

Figure 1. Monthly rainfall and average air temperature during the experimental period from September, 2013, to April 2016, at Fazenda Santa Cecília, located in Bernardino de Campos, in the state of São Paulo, Brazil. 
point at the beginning or at the end of the day, when there was no wind or rain. A total of $10 \mathrm{~mL} \mathrm{~L}^{-1}$ of the Silwet L-77 silicone surfactant (Momentive Performance Materials Inc., Waterford, NY, USA) was added to the spray mix of all treatments to enhance the efficiency of the application. The used doses were defined based on the study of Menzel \& Le Lagadec (2014) for triazoles, and of Salazar-García et al. (2007) for prohexadionecalcium. In 2014, due to the intense drought (Figure 1), the concentration of some gibberellin inhibitors was reduced, in order to avoid an excessive inhibition of vegetative growth or an excessive fruit set in the trees, which were already under severe water stress. In that year, the concentration of prohexadione-calcium was reduced to $28 \%$, while the concentrations of both paclobutrazol and uniconazole were reduced to $10 \%$. The concentration of trinexapac-ethyl was not modified, due to the lack of scientific evidences on the use of this inhibitor for shoot growth inhibition in avocado trees.

Shoot growth rate per treatment (millimeters per day) was determined between 2013 and 2015, by measuring the length of 40 shoots growing above the panicle of indeterminate inflorescences. Fruit yield was evaluated annually, on March 28, 2014, April 18, 2015, and April 7, 2016, when a minimum of 23\% dry matter content was reached in the fruit pulp (Carvalho et al., 2014).

Fruit number and weight (kg per plant) per tree were recorded annually, and cumulative fruit yield was also calculated. Yield efficiency (YE, $\mathrm{kg} \mathrm{m}^{-3}$ ) was obtained as $\mathrm{YE}=$ fruit weight $(\mathrm{kg}) /$ canopy volume $\left(\mathrm{m}^{3}\right)$. Canopy volume (V) was calculated according to Mickelbart et al. (2007), using the expression: $\mathrm{V}=4 / 3 \pi \mathrm{ab}^{2}$, where $\mathrm{a}$ is plant height (m) and $\mathrm{b}$ is average plant width $(\mathrm{m})$. The alternate bearing index (ABI) was determined according to the equation of Mickelbart et al. (2007): ABI $=(1 / n-1) \times\left\{\left[\left(\left|a_{2}-a_{1}\right|\right)\right.\right.$ $\left./\left(a_{2}+a_{1}\right)\right]+\left[\left(\left|a_{3}-a_{2}\right|\right) /\left(a_{3}+a_{2}\right)\right]+\ldots+\left[\left(\left|a_{n}-n a_{n-1}\right|\right) /\right.$ $\left.\left.\left(a_{n}+a_{n+1}\right)\right]\right\}$, where $n$ represents the number of years; and $a_{1}, a_{2}, \ldots, a_{n-1}, a_{n}$ are the yields of the corresponding years. Fruit weight and size were assessed in samples of 100 fruits randomly collected from each treatment at the time of harvest, by obtaining individual fruit mass $(\mathrm{g})$ and equatorial length and diameter $(\mathrm{mm})$. The fruit length/diameter ratio was used to determine fruit shape in the different treatments.
Data were subjected to analyses of variance using the SAS, version 9.0, statistical software (SAS Institute, Inc., Cary, NC, USA). Means were compared by Tukey's test. All statistical analyses were performed at $5 \%$ probability. Data that did not meet the assumptions of the analysis of variance were either transformed by the Box-Cox method or subjected to nonparametric analyses by the Kruskal-Wallis or Friedman tests.

\section{Results and Discussion}

The use of the gibberellin biosynthesis inhibitors significantly reduced shoot growth above the indeterminate inflorescences in nonirrigated 'Hass' avocado trees. Uniconazole stood out, causing reductions of 10,17 , and $34 \%$ in average shoot growth in 2013 , 2014, and 2015, respectively, compared with the control treatment (Table 1). This greater reduction induced by uniconazole may be attributed to its inhibitory effect at earlier steps of the gibberellin biosynthesis pathway (Graebe, 1987), even when applied at a 10\%-lower concentration, in 2014, and also after an unusual rainy period during the winter months, in 2015 (Figure 1). This change in climate conditions may explain why the inhibitory effect of uniconazole varied so much

Table 1. Average shoot growth rates of 'Hass' avocado (Persea americana) trees sprayed with different gibberellin inhibitors from 2013 to $2015^{(1)}$.

\begin{tabular}{|c|c|c|c|}
\hline \multirow[t]{2}{*}{ Treatment } & \multicolumn{3}{|c|}{ Average shoot growth rate (mm per day) } \\
\hline & $\begin{array}{c}2013 \\
(49 \mathrm{DAA})^{(2)}\end{array}$ & $\begin{array}{c}2014 \\
(33 \mathrm{DAA})^{(3)(4)}\end{array}$ & $\begin{array}{c}2015 \\
(44 \mathrm{DAA})^{(2)}\end{array}$ \\
\hline T1, water (control) & $0.98 \mathrm{ab}$ & $4.07 \mathrm{ab}$ & $5.76 \mathrm{a}$ \\
\hline $\begin{array}{l}\mathrm{T} 2,250 \mathrm{mg} \mathrm{L}^{-1} \\
\text { prohexadione-calcium }\end{array}$ & $1.06 \mathrm{a}$ & $4.45 \mathrm{a}$ & $4.36 \mathrm{~b}$ \\
\hline $\begin{array}{l}\mathrm{T} 3,2,500 \mathrm{mg} \mathrm{L}^{-1} \\
\text { trinexapac-ethyl }\end{array}$ & $1.04 \mathrm{a}$ & $4.00 \mathrm{abc}$ & $4.39 \mathrm{~b}$ \\
\hline $\begin{array}{l}\mathrm{T} 4,1,750 \mathrm{mg} \mathrm{L}^{-1} \\
\text { paclobutrazol }\end{array}$ & $0.92 \mathrm{bc}$ & $3.82 \mathrm{bc}$ & $4.67 \mathrm{~b}$ \\
\hline $\begin{array}{l}\mathrm{T} 5,350 \mathrm{mg} \mathrm{L}^{-1} \\
\text { uniconazole }\end{array}$ & $0.88 \mathrm{c}$ & $3.39 \mathrm{c}$ & $3.73 b$ \\
\hline CV $(\%)$ & 15.1 & 8.8 & 20.7 \\
\hline P-value & $<0.0001$ & 0.0003 & $<0.0001$ \\
\hline
\end{tabular}

${ }^{(1)}$ Means followed by equal letters, in the columns, do not differ by Tukey's test, at $5 \%$ probability. ${ }^{(2)}$ The original values were transformed by $\hat{y}=y^{0.5} \cdot{ }^{(3)}$ The original values were transformed by $\hat{y}=\log _{10} \cdot{ }^{(4)}$ Only $28 \%$ of the prohexadione-calcium concentration and $10 \%$ of the paclobutrazol and uniconazole concentrations were applied. DAA, days after treatment application. 
throughout the experimental period (Moreira et al., 2016).

The gibberellin inhibitors, however, did not affect the alternate bearing index (Table 2) and the production variables average fruit number and weight per plant, and yield efficiency (Table 3 ).

According to Menzel \& Le Lagadec (2014), the effects of paclobutrazol, uniconazole, and prohexadionecalcium on fruit yield of 'Hass' avocado trees are less consistent than those on the reduction of vegetative growth, as also observed in the present study. Although these inhibitors retarded shoot growth of avocado plants (Abdollahi et al., 2012), their effect on fruit yield was only indirect or secondary, since it depended on several other factors, such as product concentration and time of application, soil and climate conditions, irrigation, and plant health and nutrition (Whiley et al., 2013; Moreira et al., 2016). It should also be noted that the possible benefits of these inhibitors on yield is limited in plants exposed to environmental stresses, such as water shortage during the dry winter period in the Southeastern region of Brazil (Moreira et al., 2016).

Regarding fruit yield and size, significant increases were reported for 'Hass' avocado trees when sprayed with paclobutrazol (Whiley et al., 2013), uniconazole (Erasmus \& Brooks, 1998), and prohexadione-calcium (Salazar-García et al., 2007).

The effect of the gibberellin inhibitors on fruit size varied during the three years of evaluation (Table 4). Paclobutrazol, uniconazole, and prohexadione-calcium applications increased fruit size in 2014, but not in 2015, whereas trees sprayed with trinexapac-ethyl yielded fruit with the highest average weight in 2016.
The average weight of 'Hass' avocados significantly increased in 2014 and 2016 when the gibberellin inhibitors were applied at the same concentrations. It should be highlighted that the trees sprayed with uniconazole during flowering had larger-sized fruit and greater shoot growth reduction (Table 1), which may be an indicative of a consequent dry mass redistribution within the plant (Symons \& Wolstenholme, 1990).

The application of gibberellin inhibitors also affected the shape of 'Hass' avocado fruit, although this result was not maintained over the years (Table 4). In 2014 and 2016, all gibberellin inhibitors significantly increased mean fruit diameter. This effect could be a consequence of the steep rise in the number of cells in the fruit equatorial region induced by triazols, causing diameter expansion (Symons \& Wolstenholme, 1990). Erasmus \& Brooks (1998) reported similar results for 'Hass' avocados trees treated with $500 \mathrm{mg} \mathrm{L}^{-1}$

Table 2. Mean alternate bearing index (ABI) of nonirrigated 'Hass' avocado (Persea americana) trees sprayed with plant growth inhibitors during the 2014-2016 period.

\begin{tabular}{lc}
\hline Treatment & Mean ABI during 2014-2016 \\
\hline T1, water (control) & 0.24 \\
T2, 250 mg L-1 prohexadione-calcium & 0.23 \\
$\mathrm{~T} 3,2,500 \mathrm{mg} \mathrm{L}^{-1}$ trinexapac-ethyl & 0.15 \\
$\mathrm{~T} 4,1,750 \mathrm{mg} \mathrm{L}^{-1}$ paclobutrazol & 0.20 \\
$\mathrm{~T} 5,350 \mathrm{mg} \mathrm{L}^{-1}$ uniconazole & 0.24 \\
\hline Coefficient of variation (\%) & 55.43 \\
P-value & 0.5162 \\
\hline
\end{tabular}

${ }^{(1)}$ Obtained by the Friedman test.

Table 3. Fruit number and weight, and yield efficiency of 'Hass' avocado (Persea americana) trees sprayed with plant growth inhibitors from 2014 to 2016 period.

\begin{tabular}{|c|c|c|c|c|c|c|c|c|c|c|c|c|}
\hline \multirow[t]{2}{*}{ Treatment $^{(1)}$} & \multicolumn{4}{|c|}{ Fruits per tree } & \multicolumn{4}{|c|}{ Fruit weight (kg per tree) } & \multicolumn{4}{|c|}{ Yield efficiency $\left(\mathrm{kg} \mathrm{m}^{-3}\right)$} \\
\hline & $2014^{(2)}$ & 2015 & $2016^{(3)}$ & $\begin{array}{l}2014 \text { and } 2016 \\
\text { (cumulative) }^{(3)}\end{array}$ & $2014^{(2)}$ & 2015 & 2016 & $\begin{array}{c}2014 \text { and } 2016 \\
\text { (cumulative) }\end{array}$ & $2014^{(2)(3)}$ & 2015 & $2016^{(3)}$ & $\begin{array}{c}2014 \text { and } 2016 \\
\text { (average) }\end{array}$ \\
\hline $\mathrm{T} 1$ & 541 & 493 & 548 & 1,089 & 74 & 102 & 84 & 158 & 1.8 & 1.6 & 0.9 & 1.3 \\
\hline $\mathrm{T} 2$ & 546 & 599 & 374 & 920 & 84 & 121 & 88 & 172 & 2.2 & 1.7 & 0.7 & 1.4 \\
\hline $\mathrm{T} 3$ & 559 & 547 & 531 & 1,090 & 76 & 111 & 85 & 161 & 1.7 & 1.6 & 0.6 & 1.1 \\
\hline $\mathrm{T} 4$ & 479 & 446 & 404 & 883 & 80 & 96 & 82 & 162 & 1.8 & 1.3 & 1.1 & 1.5 \\
\hline $\mathrm{T} 5$ & 497 & 493 & 478 & 975 & 74 & 110 & 87 & 161 & 1.6 & 1.9 & 1.0 & 1.3 \\
\hline CV (\%) & 40.0 & 32.7 & 6.3 & 4.5 & 41.6 & 34.6 & 33.3 & 29.1 & 24.1 & 31.8 & 46.33 & 21.0 \\
\hline P-value & 0.9257 & 0.4389 & 0.1843 & 0.6142 & 0.9639 & 0.7375 & 0.9912 & 0.9765 & 0.2529 & 0.2026 & 0.0950 & 0.2501 \\
\hline
\end{tabular}

${ }^{(1)} \mathrm{T} 1$, water; T2, $250 \mathrm{mg} \mathrm{L}^{-1}$ prohexadione-calcium; T3, 2,500 $\mathrm{mg} \mathrm{L}^{-1}$ trinexapac-ethyl; T4, 1,750 $\mathrm{mg} \mathrm{L}^{-1}$ paclobutrazol; and T5, 350 mg L-1 uniconazole. ${ }^{(2)}$ Only $28 \%$ of the prohexadione-calcium concentration and $10 \%$ of the paclobutrazol and uniconazole concentrations were applied. ${ }^{(3)}$ The original values were transformed by $\hat{y}=1 / y$. 


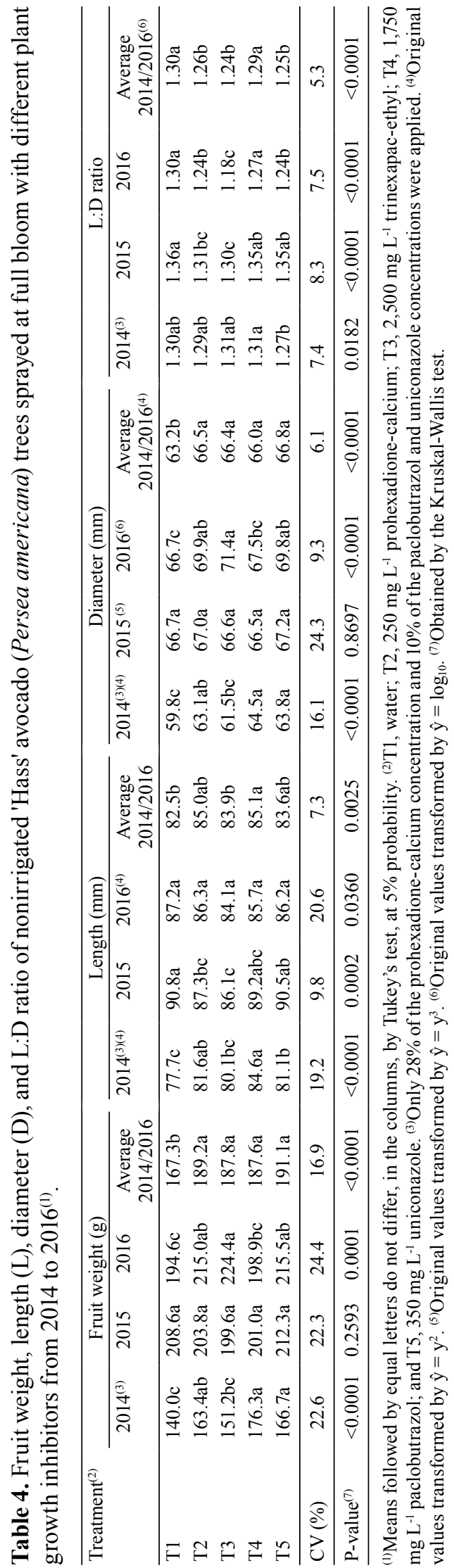

uniconazole at full bloom. In the same period, all gibberellin inhibitors significantly decreased the length/diameter ratio, except paclobutrazol, which maintained the ratio by increasing fruit length.

It was expected that the reduction in shoot growth above the panicle would increase yield and fruit size. In the present study, average fruit weight was positively affected by the application of gibberellin inhibitors, but not the production variables.

\section{Conclusions}

1. Uniconazole reduces shoot growth in nonirrigated avocado (Persea americana) 'Hass' trees, and its effect may vary depending on environmental conditions, especially water supply.

2. The evaluated gibberellin inhibitors do not affect the production variables average fruit number and weight per plant, yield efficiency, and alternate bearing index of nonirrigated 'Hass' avocado trees.

3. The application of gibberellin inhibitors at full bloom increases average fruit weight and diameter, and modifies fruit shape.

\section{Acknowledgments}

To Fundação de Amparo à Pesquisa do Estado de São Paulo (Fapesp), for financial support (project number 2013/11524-0); to Conselho Nacional de Desenvolvimento Científico e Tecnológico (CNPq), for the scholarship on scientific productivity; and to $\mathrm{Mr}$. Carlos Thomas Whately and Mr. André Dorizzotto, for providing an area of Fazenda Santa Cecília for the performance of the experiment.

\section{References}

ABDOLLAHI, M.; ESHGHI, S.; TAFAZZOLI, E.; MOOSAVI, N. Effects of paclobutrazol, boric acid and zinc sulfate on vegetative and reproductive growth of strawberry cv. Selva. Journal of Agricultural Science and Technology, v.14, p.357-363, 2012.

ACOSTA-MUÑIZ, C.H.; ESCOBAR-TOVAR, L.; VALDESRODRÍGUES, S.; FERNÁNDEZ-PAVIA, S.; ARIAS-SAUCEDO, L.J.; ESPINDOLA BARQUERA, M. de la C.; GÓMEZ LIM, M.Á. Identification of avocado (Persea americana) root proteins induced by infection with the oomycete Phytophthora cinnamomi using a proteomic approach. Physiologia Plantarum, v.144, p.5972, 2012. DOI: 10.1111/j.1399-3054.2011.01522.x.

CARDOSO, M.G.S.; SÃO JOSÉ, A.R.; VIANA, A.E.S.; MATSUMOTO, S.N.; REBOUÇAS, T.N.H. Florescimento 
e frutificação de mangueira (Mangifera indica L.) cv. Rosa promovidos por diferentes doses de paclobutrazol. Revista Brasileira de Fruticultura, v.29, p.209-212, 2007. DOI: 10.1590/ S0100-29452007000200004.

CARVALHO, C.P.; VELÁSQUEZ, M.A.; VAN ROOYEN, Z. Determination of the minimum dry matter index for the optimum harvest of 'Hass' avocado fruits in Colombia. Agronomía Colombiana, v.32, p.399-406, 2014. DOI: 10.15446/agron. colomb.v32n3.46031.

CHATZIVAGIANNIS, M.A.; SÃO JOSÉ, A.R.; BOMFIM, M.P.; OLIVEIRA JÚNIOR, M.X. de; REBOUÇAS, T.N.H. Florescimento e produtividade de mangueira 'Boubon', 'Palmer' e 'Rosa' com uso de paclobutrazol. Revista Iberoamericana de Tecnología Postcosecha, v.15, p.41-47, 2014.

ERASMUS, H.D.; BROOKS, W.H. Foliar application of uniconazole (Sunny) to avocado trees to improve fruit size and yield and to change fruit shape. South African Avocado Growers' Association Yearbook, v.21, p.52-53, 1998.

GRAEBE, J.E. Gibberellin biosynthesis and control. Annual Review of Plant Physiology, v.38, p.419-465, 1987. DOI: 10.1146/ annurev.pp.38.060187.002223.

HAWERROTH, F.J.; PETRI, J.L. Crescimento vegetativo de macieiras 'Fuji Suprema' sob influência da época de aplicação de proexadione cálcio. Revista Brasileira de Fruticultura, v.36, p.373-380, 2014. DOI: 10.1590/0100-2945-375/13.

HAWERROTH, F.J.; PETRI, J.L.; LEITE, G.B.; YOSHIKAWA, E.R. Épocas de aplicação de proexadione cálcio no controle do desenvolvimento vegetativo de macieiras 'Imperial Gala'. Revista Brasileira de Fruticultura, v.34, p.957-963, 2012. DOI: 10.1590/ S0100-29452012000400001.

LOVATT, C.J. Plant growth regulators for avocado production. California Avocado Society Yearbook, v.88, p.81-91, 2005.

MENZEL, C.M.; LE LAGADEC, M.D. Increasing the productivity of avocado orchards using high-density plantings: a review. Scientia Horticulturae, v.117, p.21-36, 2014. DOI: 10.1016/j.scienta.2014.07.013.

MICKELBART, M.V.; BENDER, G.S.; WITNEY, G.W.; ADAMS, C.; ARPAIA, M.L. Effects of clonal rootstocks on 'Hass' avocado yield components, alternate bearing, and nutrition. Journal of Horticultural Science \& Biotechnology, v.82, p.460-466, 2007. DOI: $10.1080 / 14620316.2007 .11512259$.

MOREIRA, R.A.; FERNANDES, D.R.; CRUZ, M. do C.M. da; LIMA, J.E.; OLIVEIRA, A.F. de. Water restriction, girdling and paclobutrazol on flowering and production of olive cultivars. Scientia Horticulturae, v.200, p.197-204, 2016. DOI: 10.1016/j. scienta.2016.01.014.
MOUCO, M.A. do C.; ONO, E.O.; RODRIGUES, J.D. Controle do crescimento vegetativo e floração de mangueiras cv. Kent com reguladores de crescimento vegetal. Revista Brasileira de Fruticultura, v.33, p.1043-1047, 2011. DOI: 10.1590/S010029452011000400001.

MOUCO, M.A. do C.; ONO, E.O.; RODRIGUES, J.D. Inibidores de síntese de giberelinas e crescimento de mudas de mangueira 'Tommy Atkins'. Ciência Rural, v.40, p.273-279, 2010. DOI: 10.1590/S0103-84782010000200004.

MOUCO, M.A. do C.; ONO, E.O.; RODRIGUES, J.D.; SILVA, G.J.N. Plant regulators on vegetative growth of 'Tommy Atkins' Mangoes. Acta Horticulturae, v.992, p.187-192, 2013. DOI: 10.17660/ActaHortic.2013.992.23.

SALAZAR-GARCÍA, S.; COSSIO-VARGAS, L.E.; GONZÁLEZ-DURÁN, I.J.L.; LOVATT, C.J. Foliar-applied GA advances fruit maturity and allows off-season harvest of 'Hass' avocado. HortScience, v.42, p.257-261, 2007.

SANTOS, H.G. dos; JACOMINE, P.K.T.; ANJOS, L.H.C. dos; OLIVEIRA, V.A. de; LUMBRERAS, J.F.; COELHO, M.R.; ALMEIDA, J.A. de; CUNHA, T.J.F.; OLIVEIRA, J.B. de. Sistema brasileiro de classificação de solos. 3.ed. rev. e ampl. Brasília: Embrapa, 2013. 353p.

SCHAFFER, B.; WOLSTENHOLME, B.N.; WHILEY, A.W. (Ed.). El aguacate: botánica, producción y usos. 2.ed. Chile: CABI: Ediciones Universitarias de Valparaíso, 2013. 635p.

SILVA, G.J.N.; SOUZA, E.M.; RODRIGUES, J.D.; ONO, E.O.; MOUCO, M.A.C. Uniconazole on mango floral induction cultivar 'Kent' at Submedio São Francisco Region, Brazil. Acta Horticulturae, v.884, p.677-682, 2010. DOI: 10.17660/ ActaHortic.2010.884.91.

SYMONS, P.R.R.; WOLSTENHOLME, B.N. Field trial using paclobutrazol foliar sprays on 'Hass' avocado trees. South African Avocado Growers' Association Yearbook, v.13, p.35-36, 1990.

UPRETI, K.K.; REDDY, Y.T.N.; SHIVU PRASAD, S.R.; BINDU, G.V.; JAYARAM, H.L.; RAJAN, S. Hormonal changes in response to paclobutrazol induced early flowering in mango cv. Totapuri. Scientia Horticulturae, v.150, p.414-418, 2013. DOI: 10.1016/j.scienta.2012.11.030.

WHILEY, A.W.; WOLSTENHOLME, B.N.; FABER, B.A. Manejo del cultivo. In: SCHAFFER, B.; WOLSTENHOLME, B.N.; WHILEY, A.W. (Ed.). El aguacate: botánica, producción y usos. 2.ed. Chile: CABI: Ediciones Universitarias de Valparaíso, 2013. Cap. 12, p.405-448.

$\overline{\text { Received on July 7, } 2017 \text { and accepted on November 14, } 2017}$

Pesq. agropec. bras., Brasília, v.53, n.8, p.918-923, Aug. 2018 DOI: 10.1590/S0100-204X2018000800006 